Article

\title{
Effect of Water Stress on the Physiological Characteristics of Five Basil (Ocimum basilicum L.) Cultivars
}

\author{
Iakovos Kalamartzis $^{1}$, George Menexes ${ }^{1}$, Pantazis Georgiou ${ }^{2}$ (D) and Christos Dordas ${ }^{1, *(D)}$ \\ 1 Laboratory of Agronomy, School of Agriculture, Aristotle University of Thessaloniki, \\ 54124 Thessaloniki, Greece; zisvos@yahoo.gr (I.K.); gmenexes@agro.auth.gr (G.M.) \\ 2 Laboratory of General and Agricultural Hydraulics and Land Reclamation, School of Agriculture, \\ Aristotle University of Thessaloniki, 54124 Thessaloniki, Greece; pantaz@agro.auth.gr \\ * Correspondence: chdordas@agro.auth.gr; Tel.: +30-2310-998-602; Fax: +30-2310-998-634
}

Received: 2 June 2020; Accepted: 13 July 2020; Published: 16 July 2020

\begin{abstract}
Water stress in one of the most important abiotic stresses that affects the productivity of many crop species worldwide. In addition, the climate change creates new challenges for crop adaptation especially as water resources become limited and the increase in water stress becomes more pronounced even in areas where there is adequate water supply. The objective of the present study was to determine the effect of water stress on physiological characteristics of five cultivars of basil under field conditions. Water stress affected leaf temperature, dry herb yield, leaf water potential, assimilation rate and gas exchange parameters, quantum yield, instantaneous water use efficiency (WUE), and essential oil content. From the physiological characteristics water potential and assimilation rate can be used for the selection of basil cultivars tolerant to water stress. In addition, essential oil content was lower under water stress indicating that essential oil content is correlated with water availability. From the present study it is obvious that there are tolerant basil cultivars to water stress and can be found using physiological traits such as water potential and assimilation rate and can be used to save and use water more sustainable and also conserve the water resources.
\end{abstract}

Keywords: water potential; chlorophyll content; chlorophyll fluorescence; photosynthesis; essential oil content

\section{Introduction}

One of the major problems that climate change can cause is the water scarcity and the need to reduce the irrigated areas as agriculture consumes $75-90 \%$ of the available freshwater [1]. Therefore, it is important to reduce the use of water by making the water management more efficient $[2,3]$. Better water management can contribute to maintaining agricultural sustainability and can happen by understanding the water needs of the different species and also the water needs of the different cultivars [2,3]. Also irrigation water can be managed for high yield and for better quality by using tolerant cultivars to water stress [4]. Although basil is a crop species that has high water demand the water usage can be optimized to obtain high yield without consumption of great amounts of water with the proper selection of basil cultivars [5].

Basil (Ocimum basilicum L.) is an aromatic and medicinal plant belonging to the 'Lamiaceae' family with important properties such as hypoglycemic, lowering blood pressure, antispasmodic, lowering fever, body compatibilizer stressors and strengthening the body's natural activity and anti-inflammation [6]. Basil can be used as an alternative crop in many countries of the world because of its medicinal, economic, industrial, and nutritional importance $[7,8]$. Despite the fact that is known 
for its many properties and uses basil was not studied extensively and especially its adaptation to water stress.

The main products of basil are dry leaves and flowers and also its essential oil [7,9]. In addition, basil fresh and dry leaves are used in food and spice industries and the essential oil is used in applications such as insect repellent, antibacterial, antifungal, and antioxidant agent $[7,10]$. Basil essential oil has high economic value as it contains phenyl propanoids such as eugenol, chavicol, and their derivates and important terpenoids such as monoterpene alcohol linalool, methyl cinnamate, and limonite [7,10].

Despite the fact that basil is used in cropping systems a number of different management practices were not studied and especially the effect of water stress under field conditions on the physiological characteristics of basil. In a recent study it was found that five basil cultivars respond with different ways in three irrigation levels [5]. Also purple basil was found to be very sensitive to water stress leading to a significant reduction in dry matter yield [11] which agrees with others [5]. Moreover, there are studies that were conducted in pots and were studied the effect of water stress [12-16]. In these studies it was found that when O. basilicum L. and O. americanum L. were exposed to water stress there were differences in fresh and dry weight, the essential oil content and its composition and also in other constituents such as proline content and total carbohydrate content [15]. Regarding the essential oil content there are reports that show that under water stress there is a reduction in the essential oil content, in others that there was no change and in other there was an increase in the essential oil content $[13,17]$.

There are several strategies that have been suggested to improve drought tolerance of crop plants such as molecular approaches which have yet to be fulfilled $[18,19]$. Therefore, classical approaches such as screening genotypes under field conditions and the use of physiological traits are still important in finding tolerant genotypes to water stress [20].

There are several physiological traits that can be used to screen for tolerant genotypes to water stress such as gas exchange parameters (assimilation rate $(\mathrm{A})$, stomatal conductance $\left(\mathrm{g}_{\mathrm{s}}\right)$, transpiration rate (E), intercellular $\mathrm{CO}_{2}$ concentration $\left(\mathrm{c}_{\mathrm{i}}\right)$, and the calculated WUE as $\left.\mathrm{A} / \mathrm{g}_{\mathrm{s}}\right)$, chlorophyll content, chlorophyll fluorescence, leaf water potential, and relative water content [21-28]. As far as the gas exchange parameters are concerned, they have been questioned as some authors suggest for their use [29-31] while others are against it [32,33]. Nevertheless, physiological traits have been showed a good correlation with tolerance to stresses and yield parameters and an adequate genetic variation in the evaluated population/genotype collection, and a high heritability and repeatability [20,29-31,34]. Studies including physiological parameters as breeding tools aimed to determine whether any of the photosynthetic parameters can be used for screening large sets of genotypes for their tolerance to different stresses [20]. However, usefulness of these tools to predict the performance of cultivars and especially of aromatic and medicinal plants has not been studied with due consideration [20]. Qualification of such prognostic tools may assist breeding of aromatic and medicinal plants primary aiming to create tolerant genotypes to water stress.

There are no studies that show the effect of water stress on different basil cultivars on physiological characteristics and on the essential oil content under field conditions. The objectives of the present study were: 1 . To determine the effect of water stress on physiological characteristics of basil and essential oil content of five basil cultivars under field conditions. 2. To find physiological characteristics that can be used for the selection of tolerant basil genotypes to water stress.

\section{Materials and Methods}

\subsection{Study Site}

The experiment was conducted at the University farm of Aristotle University of Thessaloniki $\left(40^{\circ} 32^{\prime} 9^{\prime \prime} \mathrm{N} 22^{\circ} 59^{\prime} 18^{\prime \prime} \mathrm{E}, 0 \mathrm{~m}\right)$ for two years (2015 and 2016). The soil type was a clay loam with organic matter $12.40 \mathrm{~g} \mathrm{~kg}^{-1}, \mathrm{pH}\left(1: 1 \mathrm{H}_{2} \mathrm{O}\right) 7.77, \mathrm{EC}\left(\mathrm{dS} \mathrm{m}^{-1}\right) 1.07$, and $\mathrm{CaCO}_{3} 11.3 \%$. The physical and hydraulic properties were determined in an undisturbed soil sample with pressure plate extractor 
method [35] at 0-30 $\mathrm{cm}$ : bulk density $\left(\mathrm{Mg} \mathrm{m}^{-3}\right)$ 1.3, field capacity (at $\left.10 \mathrm{kPa}, \mathrm{m}^{3} \mathrm{~m}^{-3}\right) 0.373$ and wilting point (at $1500 \mathrm{kPa}, \mathrm{m}^{3} \mathrm{~m}^{-3}$ ) 0.132 . The previous crop was durum wheat (Triticum turgidum subsp. durum L.) and after harvest the wheat straw was baled and removed. The conventional tillage was used and the experimental site are moldboard plowed, harrowed and a cultivator was used. Fertilizer containing $\mathrm{N}$ and $\mathrm{P}$ was applied before planting at the following rates of 100 and $50 \mathrm{~kg} \mathrm{ha}^{-1}$, respectively. Weed control was obtained by hand weeding and tilling when necessary. Weather conditions were recorded daily with an automatic weather station which was close to the experimental site and were reported as mean monthly data for both years (Table 1). Both years showed difference regarding the weather conditions as temperatures were lower during May 2015 and rainfall was higher during 2015 in contrast during the 2016 rainfall was much lower. Moreover, the other parameters were similar with the 30 years' average values during the irrigation period (from June to August).

Table 1. The main weather parameters (mean temperature and rainfall) for the two growing seasons of experimentation at Thermi Greece and its comparison to the 30-year average. The weather data were recorded with an automatic weather station close to the experimental site.

\begin{tabular}{ccccccc}
\hline & \multicolumn{3}{c}{ Mean Temperature $\left({ }^{\circ} \mathbf{C}\right)$} & \multicolumn{3}{c}{ Rainfall $(\mathbf{m m})$} \\
\hline Month & $\mathbf{2 0 1 5}$ & $\mathbf{2 0 1 6}$ & 30 Years Average & $\mathbf{2 0 1 5}$ & $\mathbf{2 0 1 6}$ & 30 Years Average \\
\hline March & 9.1 & 11.33 & 9.6 & 99.40 & 129.40 & 31 \\
April & 13.5 & 14.56 & 13.9 & 14.40 & 90.00 & 38 \\
May & 20.1 & 19.22 & 19.3 & 19.80 & 73.00 & 44 \\
June & 23.2 & 25.87 & 24.5 & 96.20 & 15.20 & 32 \\
July & 27.5 & 27.85 & 26.7 & 8.20 & 1.20 & 31 \\
August & 27.1 & 27.11 & 26 & 1.08 & 0.83 & 24 \\
\hline
\end{tabular}

\subsection{Genotypes Used in the Study}

Five basil cultivars were used in this study that had differences in earliness, essential oil content characteristics. These cultivars were selected from a two years field study during 2013 and 2014 where twenty basil cultivars were evaluated for their growth, dry matter yield and essential oil content [36]. In addition, the same cultivars were screened using agronomic traits for their water use efficiency under field conditions [5]. The cultivars that were used were Mrs Burns which is an early, vigorous plant with a distinctive lemon scent, Cinnamon which is also an early and vigorous plant with a distinctive cinnamon scent, Sweet is medium maturity of Genovese type cultivar, Thai is a late cultivar with mild anise or liquorice flavor and Red Rubin is a late maturing cultivars with a good red for cut leaf.

\subsection{Experimental Design and Crop Management}

The experimental design that was followed was the Randomized Complete Block Design (RCBD) in a split-split plot arrangement, where irrigation levels were the main plots, cultivars were the sub-plots, and the repeated measures on the three different growth stages were the sub-sub plots. In addition, we used four replications (blocks) per treatment combination and each block was divided in three strips which were the three irrigation levels and within each strip the five cultivars were randomized. Every experimental plot was $5 \mathrm{~m}$ in length and $2.5 \mathrm{~m}$ in width with five rows $50 \mathrm{~cm}$ apart and the total size of each plot was $12.5 \mathrm{~m}^{2}$. Seedlings were prepared and transplanted in the field. On the 4 April 2015 and 19 March 2016 for the 2015 and 2016 growing season respectively seeds were sown in a mixture of peat and perlite (9:1). On 16 May 2015 and on 25 April 2016 when the seedlings were about $10 \mathrm{~cm}$ in plant height they were transplanted in the field at a rate of 8 plants $\mathrm{m}^{-2}$.

Three irrigation treatments were applied at $100 \%, 70 \%$, and $40 \%$ of the net irrigation requirements $\left(\mathrm{IR}_{\mathrm{n}}\right)$ and are presented as $\mathrm{d}_{100}, \mathrm{~d}_{70}$ and $\mathrm{d}_{40}$ respectively. IRn was calculated from the equation:

$$
\mathrm{IR}_{\mathrm{n}}=\mathrm{ET}_{\mathrm{c}}-\mathrm{P}_{\mathrm{e}}-\mathrm{CR}+\mathrm{D}_{\mathrm{p}}+\mathrm{R}_{\text {off }} \pm \Delta \mathrm{SM}
$$


were $\mathrm{ET}_{\mathrm{C}}$ was the crop evapotranspiration, $\mathrm{P}_{\mathrm{e}}$ was the effective rainfall and was taken into account only when it was higher than $4 \mathrm{~mm}$ on any day and entire rainfall was considered as effective rainfall, $C R$ was the capillary rise from the groundwater table, $D_{p}$ was the deep percolation, $R_{\text {off }}$ was the runoff and $\Delta S M$ was the change of soil moisture content in the root zone. In this study, the $C R, D_{p}$ and $R_{\text {off }}$ were negligible because (a) there is no shallow water table problem in the experimental area, thus CR value was assumed to be zero, (b) $D_{p}$ was not assumed since the amount of irrigation water was equal to the deficit amount in the root zone and (c) irrigation was performed with drip irrigation and there was no runoff. Besides, irrigation was applied whenever $\mathrm{ET}_{\mathrm{C}}$ reached $50 \mathrm{~mm}$.

We calculated the reference evapotranspiration $\left(\mathrm{ET}_{\mathrm{O}}\right)$ with the method Penman-Monteith [37] with the following equation:

$$
\mathrm{ET}_{\mathrm{o}}=\left[0.408 \Delta\left(\mathrm{R}_{\mathrm{n}}-\mathrm{G}\right)+\gamma[900 /(\mathrm{T}+273)] \mathrm{u}^{2}\left(\mathrm{e}_{\mathrm{s}}-\mathrm{e}_{\mathrm{a}}\right)\right] /\left[\Delta+\gamma\left(1+0.34 \mathrm{u}^{2}\right)\right]
$$

where $\mathrm{ET}_{\mathrm{o}}$ is the reference evapotranspiration $\left(\mathrm{mm} \mathrm{day}^{-1}\right), \mathrm{R}_{\mathrm{n}}$ is net radiation at the crop surface (MJ $\mathrm{m}^{-2}$ day $\left.^{-1}\right), \mathrm{G}$ is soil heat flux density $\left(\mathrm{MJ} \mathrm{m}^{-2}\right.$ day $\left.^{-1}\right), \mathrm{T}$ is mean daily air temperature at $2 \mathrm{~m}$ height $\left({ }^{\circ} \mathrm{C}\right), \mathrm{u}^{2}$ is wind speed at $2 \mathrm{~m}$ height $\left(\mathrm{m} \mathrm{s}^{-1}\right)$, es is saturation vapour pressure $\left(\mathrm{kP}_{\mathrm{a}}\right), \mathrm{e}_{\mathrm{a}}$ is actual vapour pressure $\left(\mathrm{kP}_{\mathrm{a}}\right), \mathrm{e}_{\mathrm{s}}-\mathrm{e}_{\mathrm{a}}$ is the saturation vapour pressure deficit $(\mathrm{kPa}), \Delta$ is the slope vapour pressure curve $\left(\mathrm{kP}_{\mathrm{a}}{ }^{\circ} \mathrm{C}^{-1}\right), \gamma$ is the psychrometric constant $\left(\mathrm{kP}_{\mathrm{a}}{ }^{\circ} \mathrm{C}^{-1}\right)$.

Crop evapotranspiration (ETc) was calculated with the following equation:

$$
\mathrm{ET}_{\mathrm{c}}=\mathrm{k}_{\mathrm{c}} \times \mathrm{ET}_{\mathrm{o}}
$$

where $\mathrm{k}_{\mathrm{c}}$ is the crop coefficient.

The following values of crop coefficient $\left(\mathrm{k}_{\mathrm{c}}\right)$ were used: for the beginning of flowering, 0.9 ; for full bloom, 1.1; for the end of flowering, 1.0 [38].

Soil moisture was kept at $70 \%$ of field capacity which is considered adequate for plant growth in all growth stages at full irrigation $\left(\mathrm{d}_{100}\right)$. The differentiation of irrigation levels started when the plants were at vegetative stage and 40 days after transplantation and 30 days before anthesis. After transplantation, $30 \mathrm{~mm}$ of irrigation water was applied in order to promote the establishment of the newly transplanted plants. The water was applied with a drip irrigation system, after transplanting with the drippers spaced at $50 \mathrm{~cm}$ intervals the water supply of the drippers was $4 \mathrm{~L} \mathrm{~h}^{-1}$. The drip irrigation lines were placed every other row. The same irrigation system was extensively used in other experiments $[5,20]$.

\subsection{Dry Herb Yield Determination}

In order to determine the dry herb yield three crop sampling were conducted. The growth stages that the sampling were done were at the beginning of flowering, full bloom and end of flowering and started from the first week of July until the first week of August in both years. One $\mathrm{m}^{2}$ was randomly selected from each plot and was harvested from the inner row. Total eight plants were sampled from each plot per sampling. The plants were cut at the ground level and let it dry at room temperature for a week, when a constant weight was reached plants were weighted to obtain the dry weight. Following the leaves and flowers of the samples were separated from the stems by hand and weighed and this was the dry herb yield. A subsample of $0.5 \mathrm{~kg}$ biomass was dried at $65^{\circ} \mathrm{C}$ to constant weight to determine the relative water content and the dry weight yield

\subsection{Essential Oil Determination}

Essential oil content was determined using dry herb yield of $40 \mathrm{~g}$ and was subjected to a $3 \mathrm{~h}$ water-distillation using a Clevenger apparatus (Sigma, London, UK), and the extracted essential oils were stored at $-20^{\circ} \mathrm{C}$. The essential oil content of the plants was determined by a volumetric method $\left(\mathrm{mL} 100 \mathrm{~g}^{-1}\right)$ [39]. 


\subsection{Gas-Exchange Measurements}

Gas exchange parameters were determined with a portable photosynthesis system (LCi-SD, ADC BioScientific Ltd., Herts, UK) equipped with a square $\left(6.25 \mathrm{~cm}^{2}\right)$ chamber was used for measuring $\mathrm{CO}_{2}$ assimilation rate (A), transpiration rate (E), stomatal conductance to water vapour $\left(\mathrm{g}_{\mathrm{s}}\right)$, and intercellular $\mathrm{CO}_{2}$ concentration $\left(\mathrm{C}_{\mathrm{i}}\right)$ at the beginning of flowering, full bloom and end of flowering. Measurements were performed on six plants from each plot from 09:00-12:00 in the morning to avoid high vapor-pressure deficit and photoinhibition at midday. Instantaneous water use efficiency (WUE) was obtained by dividing A by stomatal conductance $\left(\mathrm{g}_{\mathrm{s}}\right)[40]$.

\subsection{Chlorophyll Fluorescence}

The minimum Chl fluorescence $\left(\mathrm{F}_{0}\right)$ and the maximum Chl fluorescence $\left(\mathrm{F}_{\mathrm{m}}\right)$ were measured also in situ with the portable Z995 FluorPen PAR (Qubit Biology Inc. Kingston, ON, Canada). For each plot 10 young fully expanded leaves were used before each sampling. The maximum quantum efficiency of photosystem (PS) II was calculated as $\mathrm{F}_{\mathrm{v}} / \mathrm{F}_{\mathrm{m}}\left(\mathrm{F}_{\mathrm{v}}=\mathrm{F}_{\mathrm{m}}-\mathrm{F}_{0}\right)$.

\subsection{Chlorophyll Content}

Chlorophyll content readings (SPAD units) were taken with a hand-held dual-wavelength meter (SPAD 502, Chlorophyll meter, Minolta Camera Co., Ltd., Osaka, Japan). For each plot 10 young fully expanded leaves were used before each sampling. The instrument stored and automatically averaged these readings to generate one reading per plot.

\subsection{Leaf Temperature}

Leaf temperature was determined with a portable infrared thermometer (Fluke 561, Fluke, Son, Eindhoven, The Netherlands) by measuring 10 leaves per plot and taking an average value.

\subsection{Water Potential}

Midday leaf water potential was measured with a pressure chamber (Plant Moisture System-Digital model: Digital Plant Moisture System, Skye Instruments Ltd., Llandrindod Wells, UK) within two hours past solar noon twice at the full bloom and after full bloom. Four leaves from each plot was used each collected from different plants, were used for the measurements.

\subsection{Statistical Analysis}

The data were analyzed within the methodological frame of Mixed Linear Models with the Analysis of Variance (ANOVA) method according to the model that involves the effects (main and interactions) of four factors: 2 "years" $\times 3$ "irrigation levels" $\times 5$ "cultivars" $\times 3$ "growth stages". The experiment was installed according to the Randomized Complete Block Design (RCBD) in a split-split-split-plot arrangement, utilizing data from four blocks per combined treatment. The "years" were considered as the main plots, "irrigation levels" were considered as the sub-plots, "cultivars" were considered as the sub-sub-plots, and "growth stages" were considered as the sub-sub-sub plots [41,42]. A combined over years ANOVA was performed according to the previously described experimental setup. Within each year the basic experimental design was the RCBD in a split-split plot arrangement: "irrigation levels" were the main plots, "cultivars" were the sub-plots, and "growth stages" were the sub-sub plots, since there were repeated measurements on the same experimental unit. The combined analysis over years corresponds statistically to a split-split-split plot analysis, where the levels of the factor "years" are considered as the main plots, the irrigation levels as the sub-plots and so on. Data for leaf temperature and assimilation rate were $\log _{10}(X+1)$ transformed in order the corresponding models' residuals to achieve normality and homoscedasticity. Pair-wise differences between treatments' means were tested with the protected Least Significant Difference (LSD) criterion. The significance level of all hypothesis testing procedures was preset at $\mathrm{a}=0.05(p \leq 0.05)$. The SPSS software (ver. 17, 
SPSS Inc., Chicago, USA) was used for the statistical analyzes. One of the authors developed and programmed a special SPSS's syntax code for performing the statistical analysis and the testing of the proposed mixed linear model.

\section{Results}

Most of the characteristics were affected by the main effect of year $(\mathrm{Y})$, irrigation $(\mathrm{W})$, cultivar (G), and growth stages (S) and also by some of their two way and higher order interactions (Table 1). The two-way interaction "cultivar $\times$ year" had a statistically significant effect on all plant characteristics except on leaf temperature and assimilation rate. The effect of the interaction "irrigation $\times$ year" was only statistically significant for the water potential, stomatal conductance, evapotranspiration, $C_{i}$ and intrinsic WUE. The interaction "growth stages $\times$ year" had a statistically significant effect on all characteristics. The effect of the interaction "cultivar $\times$ growth stages" was statistically significant for all the characteristics except the water potential and E. The interaction "irrigation $\times$ growth stages" had a statistically significant effect only on leaf temperature, water potential, and intrinsic WUE. The interaction "cultivar $\times$ irrigation" effect was only statistically significant for chlorophyll content, water potential, and intrinsic WUE. The three-way interaction "cultivar $\times$ year $\times$ irrigation" was statistically significant only for water potential. The interaction "cultivar $\times$ irrigation $\times$ growth stages" effect was statistically significant for essential oil content. The interaction "irrigation $\times$ year $\times$ growth stage" had a statistically significant effect only on water potential. The interaction "cultivar $\times$ year $\times$ growth stages" effect was statistically significant for all the measured plant characteristics except the chlorophyll content, water potential, gs, and E. Finally, the four-way interaction "cultivar $\times$ year $\times$ irrigation $\times$ growth stages" had a statistically significant effect on leaf temperature, essential oil content, water potential and intrinsic WUE. Based on Table 2, for all measured plant characteristics, there are significant two-way and three-way interactions (and in three cases, there are significant four-way interactions) that involve the combination of the four factors, in some cases, in pairs, and in others, in triplets. Consequently, there is a point to present the synergistic effect of cultivar, irrigation, year, and growing stage; that is, to present the mean values for all treatments' combinations in Tables 2-6 and in Figures 1 and 2.

\subsection{Chlorophyll Content}

Chlorophyll content readings were not affected by the irrigation treatment for the three measurements and it was affected by the year as it was higher during the second year (2016) and also by the cultivars (Tables 2 and 3). In addition, chlorophyll content was affected by the growth stage as it was higher at the beginning of flowering. The irrigation level affected only the chlorophyll content of Thai during the 2016 period. The highest chlorophyll content was found at Cinnamon at the two growth stages and at the third growth stage was higher at Red Rubin and Thai.

\subsection{Leaf Temperature}

Leaf temperature was affected by all the parameters that were studied and was higher at $\mathrm{d}_{40}$ compared with the $d_{100}$ in some of the treatments. At the first measurement higher leaf temperature was found at the Cinnamon and Red Rubin. In addition, higher leaf temperature was found at 2015 compared with the 2016. At full bloom higher leaf temperature was found at Cinnamon and at $\mathrm{d}_{40}$ and at 2015. At the end of flowering the differences were less pronounced and also Cinnamon had the higher leaf temperature and also at $\mathrm{d}_{40}$ (Table 3 ). 
Table 2. Analysis of variance results (significance of the effects) for testing the effects (main and interactions) of Year (Y), Irrigation (W), Cultivar (C), and Growth Stages (S) on the measured plant characteristics.

\begin{tabular}{|c|c|c|c|c|c|c|c|c|c|c|c|c|c|c|c|}
\hline Parameters & $\begin{array}{c}\text { Growth } \\
\text { Stages (S) }\end{array}$ & $\begin{array}{l}\text { Year } \\
\text { (Y) }\end{array}$ & $\begin{array}{l}\text { Irrigation } \\
\text { (W) }\end{array}$ & $\begin{array}{c}\text { Genotype } \\
\text { (G) }\end{array}$ & $\mathbf{G} \times \mathbf{Y}$ & $\mathbf{W} \times \mathbf{Y}$ & $\mathbf{S} \times \mathbf{Y}$ & $\mathrm{G} \times \mathrm{S}$ & $\mathbf{W} \times \mathbf{S}$ & $\mathbf{G} \times \mathbf{W}$ & $\begin{array}{c}\mathrm{G} \times \mathrm{Y} \\
\times \mathbf{W}\end{array}$ & $\begin{array}{c}\mathbf{G} \times \mathbf{W} \\
\times \mathbf{S}\end{array}$ & $\begin{array}{c}\mathbf{W} \times \mathbf{Y} \\
\times \mathrm{S}\end{array}$ & $\begin{array}{c}\mathrm{G} \times \mathrm{Y} \\
\times \mathrm{S}\end{array}$ & $\begin{array}{c}\mathbf{G} \times \mathbf{Y} \times \\
\mathbf{W} \times \mathbf{S}\end{array}$ \\
\hline Chlorophyll content & $* * *$ & $* * *$ & NS & $* * *$ & $* * *$ & NS & $* * *$ & $* * *$ & NS & ** & NS & NS & NS & NS & NS \\
\hline Chlorophyll Fluorescence & $* * *$ & NS & NS & $* * *$ & $* * *$ & NS & $* * *$ & $* * *$ & NS & NS & NS & NS & NS & $* * *$ & NS \\
\hline Leaf temperature & $* * *$ & * & $* * *$ & $* * *$ & NS & NS & * & $* * *$ & * & NS & NS & NS & NS & $* * *$ & * \\
\hline Essential oil content & $* * *$ & NS & ** & $* * *$ & $* * *$ & NS & $* * *$ & $* * *$ & NS & NS & NS & * & NS & * & $* *$ \\
\hline Dry weight of herbal material & $* * *$ & $* * *$ & $* *$ & $* * *$ & $* * *$ & NS & $* * *$ & $* * *$ & NS & NS & NS & NS & NS & $* * *$ & NS \\
\hline Water potential & NS & $* * *$ & $* * *$ & $* * *$ & $* * *$ & $* * *$ & * & NS & $* * *$ & $* *$ & $* *$ & NS & $* * *$ & NS & $*$ \\
\hline Assimilation rate $\mathrm{CO}_{2}(\mathrm{~A})$ & $* * *$ & NS & $* *$ & $* *$ & NS & NS & ** & $* * *$ & NS & NS & NS & NS & NS & $* * *$ & NS \\
\hline Stomatal conductance $\left(\mathrm{g}_{\mathrm{s}}\right)$ & $* * *$ & * & $* * *$ & $* * *$ & $* * *$ & ** & $* * *$ & NS & NS & NS & NS & NS & NS & NS & NS \\
\hline Evapotranspiration (E) & $* * *$ & * & $* * *$ & $* * *$ & $* * *$ & ** & $* * *$ & NS & NS & NS & NS & NS & NS & NS & NS \\
\hline Internal leaf $\mathrm{CO}_{2}$ concentration $\left(\mathrm{c}_{\mathrm{i}}\right)$ & $* * *$ & ** & NS & $* * *$ & $* *$ & NS & $* * *$ & $* * *$ & NS & NS & NS & NS & NS & $* * *$ & $*$ \\
\hline Intrinsic Water use efficiency (WUE $\mathrm{A} / \mathrm{gs}$ ) & $* * *$ & NS & ** & $* * *$ & $* * *$ & NS & $* * *$ & $* * *$ & * & NS & NS & NS & NS & $* * *$ & ** \\
\hline
\end{tabular}

${ }^{*}$ Significant at 0.05 significance level. ${ }^{* *}$ Significant at 0.01 significance level. ${ }^{* * *}$ Significant at 0.001 significance level. NS, non significant $(p>0.05)$.

Table 3. Combined effect of Years $(2015,2016)$, Cultivars, Irrigation treatments and Stages of development on Chlorophyll content, Leaf temperature and Water potential. Data presented are mean values, where LSD is the least significant difference at the 0.05 significance level.

\begin{tabular}{|c|c|c|c|c|c|c|c|c|c|c|}
\hline \multirow{3}{*}{ Cultivars } & \multirow{3}{*}{$\begin{array}{c}\text { Irrigat. } \\
\text { Treatments }\end{array}$} & \multirow{3}{*}{ Stage } & \multicolumn{2}{|c|}{ Chlorophyll Content } & \multicolumn{4}{|c|}{ Leaf Temperature } & \multicolumn{2}{|c|}{ Water Potential } \\
\hline & & & \multirow{2}{*}{2015} & \multirow{2}{*}{2016} & \multicolumn{2}{|c|}{2015} & \multicolumn{2}{|c|}{2016} & \multirow{2}{*}{2015} & \multirow{2}{*}{2016} \\
\hline & & & & & Transformed $^{1}$ & Actual $^{2}$ & Transformed $^{1}$ & Actual $^{2}$ & & \\
\hline \multirow{9}{*}{ Mrs Burns } & $\mathrm{d}_{40}$ & \multirow{4}{*}{ 1rst GS } & 35.28 & 40.90 & 1.487 & 29.72 & 1.476 & 28.90 & & \\
\hline & $\mathrm{d}_{70}$ & & 34.23 & 37.28 & 1.481 & 29.28 & 1.457 & 27.66 & & \\
\hline & $\mathrm{d}_{100}$ & & 35.10 & 38.15 & 1.485 & 29.58 & 1.453 & 27.38 & & \\
\hline & $\mathrm{d}_{40}$ & & 29.40 & 31.58 & 1.525 & 32.54 & 1.507 & 31.13 & 9.90 & 4.94 \\
\hline & $\mathrm{d}_{70}$ & \multirow[t]{2}{*}{ 2nd GS } & 29.70 & 33.10 & 1.500 & 30.63 & 1.481 & 29.25 & 4.28 & 2.90 \\
\hline & $\mathrm{d}_{100}$ & & 28.98 & 31.28 & 1.494 & 30.21 & 1.465 & 28.16 & 2.85 & 2.79 \\
\hline & $\mathrm{d}_{40}$ & \multirow{3}{*}{ 3rd GS } & 26.95 & 27.55 & 1.509 & 31.29 & 1.468 & 28.41 & 11.00 & 3.62 \\
\hline & $\mathrm{d}_{70}$ & & 27.23 & 26.08 & 1.517 & 31.90 & 1.481 & 29.25 & 5.16 & 3.50 \\
\hline & $\mathrm{d}_{100}$ & & 31.10 & 27.98 & 1.505 & 30.98 & 1.436 & 26.35 & 6.04 & 3.55 \\
\hline
\end{tabular}


Table 3. Cont

\begin{tabular}{|c|c|c|c|c|c|c|c|c|c|c|}
\hline \multirow{3}{*}{ Cultivars } & \multirow{3}{*}{$\begin{array}{c}\text { Irrigat. } \\
\text { Treatments }\end{array}$} & \multirow{3}{*}{ Stage } & \multicolumn{2}{|c|}{ Chlorophyll Content } & \multicolumn{4}{|c|}{ Leaf Temperature } & \multicolumn{2}{|c|}{ Water Potential } \\
\hline & & & \multirow{2}{*}{2015} & \multirow{2}{*}{2016} & \multicolumn{2}{|c|}{2015} & \multicolumn{2}{|c|}{2016} & \multirow{2}{*}{2015} & \multirow{2}{*}{$201 \epsilon$} \\
\hline & & & & & Transformed $^{1}$ & Actual $^{2}$ & Transformed $^{1}$ & Actual $^{2}$ & & \\
\hline \multirow{9}{*}{ Cinnamon } & $\mathrm{d}_{40}$ & \multirow{3}{*}{ 1rst GS } & 41.80 & 47.50 & 1.495 & 30.25 & 1.499 & 30.59 & & \\
\hline & $\mathrm{d}_{70}$ & & 41.80 & 45.73 & 1.489 & 29.81 & 1.483 & 29.41 & & \\
\hline & $\mathrm{d}_{100}$ & & 42.40 & 47.45 & 1.498 & 30.49 & 1.476 & 28.96 & & \\
\hline & $\mathrm{d}_{40}$ & \multirow{3}{*}{ 2nd GS } & 38.98 & 43.18 & 1.558 & 35.23 & 1.529 & 32.91 & 15.05 & 4.41 \\
\hline & $\mathrm{d}_{70}$ & & 38.47 & 40.55 & 1.509 & 31.33 & 1.501 & 30.73 & 6.67 & 2.83 \\
\hline & $\mathrm{d}_{100}$ & & 35.90 & 39.83 & 1.493 & 30.11 & 1.500 & 30.62 & 3.63 & 3.46 \\
\hline & $\mathrm{d}_{40}$ & \multirow{3}{*}{ 3rd GS } & 34.68 & 39.10 & 1.525 & 32.48 & 1.491 & 30.03 & 10.63 & 3.66 \\
\hline & $\mathrm{d}_{70}$ & & 31.78 & 36.63 & 1.513 & 31.60 & 1.471 & 28.60 & 10.62 & 3.79 \\
\hline & $\mathrm{d}_{100}$ & & 34.50 & 36.18 & 1.501 & 30.70 & 1.468 & 28.54 & 7.71 & 4.02 \\
\hline \multirow{9}{*}{ Sweet } & $\mathrm{d}_{40}$ & \multirow{4}{*}{ 1rst GS } & 36.83 & 38.28 & 1.545 & 34.15 & 1.511 & 31.46 & & \\
\hline & $\mathrm{d}_{70}$ & & 35.08 & 39.33 & 1.515 & 31.75 & 1.502 & 30.75 & & \\
\hline & $\mathrm{d}_{100}$ & & 33.95 & 37.85 & 1.484 & 29.48 & 1.530 & 32.98 & & \\
\hline & $\mathrm{d}_{40}$ & & 33.63 & 38.13 & 1.507 & 31.18 & 1.483 & 29.45 & 14.20 & 4.17 \\
\hline & $\mathrm{d}_{70}$ & \multirow[t]{2}{*}{ 2nd GS } & 26.73 & 34.98 & 1.497 & 30.41 & 1.465 & 28.29 & 6.15 & 2.93 \\
\hline & $\mathrm{d}_{100}$ & & 26.68 & 35.53 & 1.502 & 30.80 & 1.467 & 28.47 & 2.55 & 2.79 \\
\hline & $\mathrm{d}_{40}$ & \multirow{3}{*}{ 3rd GS } & 35.28 & 35.78 & 1.487 & 29.70 & 1.450 & 27.22 & 10.09 & 2.83 \\
\hline & $\mathrm{d}_{70}$ & & 30.80 & 36.88 & 1.475 & 28.91 & 1.443 & 26.75 & 10.52 & 2.65 \\
\hline & $\mathrm{d}_{100}$ & & 29.30 & 34.43 & 1.478 & 29.09 & 1.450 & 27.27 & 10.57 & 2.41 \\
\hline \multirow{9}{*}{ Red Rubin } & $\mathrm{d}_{40}$ & \multirow{3}{*}{ 1rst GS } & 40.25 & 40.70 & 1.559 & 35.37 & 1.508 & 31.27 & & \\
\hline & $\mathrm{d}_{70}$ & & 38.00 & 40.10 & 1.532 & 33.03 & 1.545 & 34.13 & & \\
\hline & $\mathrm{d}_{100}$ & & 37.40 & 41.70 & 1.496 & 30.37 & 1.494 & 30.24 & & \\
\hline & $\mathrm{d}_{40}$ & \multirow{3}{*}{ 2nd GS } & 27.90 & 40.05 & 1.526 & 32.56 & 1.479 & 29.17 & 9.70 & 3.97 \\
\hline & $\mathrm{d}_{70}$ & & 27.63 & 38.50 & 1.521 & 32.24 & 1.468 & 28.42 & 4.15 & 2.70 \\
\hline & $\mathrm{d}_{100}$ & & 30.68 & 40.93 & 1.506 & 31.09 & 1.464 & 28.22 & 1.66 & 3.38 \\
\hline & $\mathrm{d}_{40}$ & \multirow{3}{*}{ 3rd GS } & 34.35 & 34.35 & 1.493 & 30.24 & 1.450 & 27.24 & 2.74 & 2.69 \\
\hline & $\mathrm{d}_{70}$ & & 31.68 & 31.68 & 1.491 & 29.98 & 1.459 & 27.82 & 10.15 & 2.82 \\
\hline & $\mathrm{d}_{100}$ & & 34.08 & 34.08 & 1.491 & 30.04 & 1.451 & 27.34 & 2.97 & 2.50 \\
\hline
\end{tabular}


Table 3. Cont

\begin{tabular}{|c|c|c|c|c|c|c|c|c|c|c|}
\hline \multirow{3}{*}{ Cultivars } & \multirow{3}{*}{$\begin{array}{c}\text { Irrigat. } \\
\text { Treatments }\end{array}$} & \multirow{3}{*}{ Stage } & \multicolumn{2}{|c|}{ Chlorophyll Content } & \multicolumn{4}{|c|}{ Leaf Temperature } & \multicolumn{2}{|c|}{ Water Potential } \\
\hline & & & \multirow{2}{*}{2015} & \multirow{2}{*}{2016} & \multicolumn{2}{|c|}{2015} & \multicolumn{2}{|c|}{2016} & \multirow{2}{*}{2015} & \multirow{2}{*}{2016} \\
\hline & & & & & Transformed $^{1}$ & Actual $^{2}$ & Transformed $^{1}$ & Actual $^{2}$ & & \\
\hline \multirow{9}{*}{ Thai } & $\mathrm{d}_{40}$ & \multirow{4}{*}{ 1rst GS } & 37.00 & 35.55 & 1.554 & 34.93 & 1.463 & 28.06 & & \\
\hline & $\mathrm{d}_{70}$ & & 35.70 & 41.20 & 1.528 & 32.76 & 1.459 & 27.83 & & \\
\hline & $\mathrm{d}_{100}$ & & 35.28 & 40.60 & 1.492 & 30.03 & 1.481 & 29.33 & & \\
\hline & $\mathrm{d}_{40}$ & & 28.83 & 38.30 & 1.513 & 31.62 & 1.500 & 30.80 & 14.67 & 3.27 \\
\hline & $\mathrm{d}_{70}$ & \multirow[t]{2}{*}{ 2nd GS } & 30.85 & 37.95 & 1.491 & 29.99 & 1.461 & 27.99 & 4.45 & 3.41 \\
\hline & $\mathrm{d}_{100}$ & & 30.48 & 37.75 & 1.479 & 29.1 & 1.464 & 28.24 & 1.61 & 3.10 \\
\hline & $\mathrm{d}_{40}$ & \multirow{3}{*}{ 3rd GS } & 37.48 & 34.35 & 1.485 & 29.69 & 1.459 & 27.84 & 5.81 & 2.67 \\
\hline & $\mathrm{d}_{70}$ & & 41.80 & 40.40 & 1.481 & 29.33 & 1.449 & 27.16 & 5.44 & 2.40 \\
\hline & $\mathrm{d}_{100}$ & & 37.03 & 39.43 & 1.473 & 28.77 & 1.456 & 27.61 & 8.25 & 2.30 \\
\hline $\mathrm{LSD}_{0.05}$ & & & 4.78 & 4.78 & 0.031 & & 0.031 & & 3.47 & 3.47 \\
\hline $\mathrm{CV} \%$ & & & 9.5 & & 5.1 & & & & 47.2 & \\
\hline
\end{tabular}

${ }^{1}$ Data presented in column titled "Transformed" are means of $\log _{10}(X+1)$ transformed values. ${ }^{2}$ Values in column titled "Actual" correspond to the means computed from raw data. 


\subsection{Water Potential}

Midday leaf water potential was affected by the year, irrigation and genotype and also by their interaction except from genotype and growth stage, genotype, irrigation and growth stage and genotype, year and growth stage. It was higher at $d_{40}$ compared with the $d_{100}$ and also at the first measurement at Cinnamon. At the second measurement was higher at the $d_{40}$ compared with the $d_{100}$. The cultivars that showed higher water potential were Cinnamon and Sweet and lower at Thai and Red Rubin. There was also difference between the two years of the study and it was higher at 2015 compared with the 2016 growing season (Table 3).

\subsection{Gas-Exchange Parameters}

Gas exchange parameters and more specifically assimilation rate (A), evapotranspiration rate (E), stomatal conductance $\left(\mathrm{g}_{\mathrm{s}}\right)$, and intercellular $\mathrm{CO}_{2}$ concentration $\left(\mathrm{C}_{\mathrm{i}}\right)$ were affected by the growth stages, irrigation, genotype and the interactions between growth stages and year, growth stages and genotypes, and the three way interaction of growth stages, year and genotypes. At the beginning of flowering there was difference among the cultivars at the assimilation rate and the highest was found at Thai and Sweet and the lower at Mrs Burns and Cinnamon. In addition, during the two growth stages there was difference among the irrigation treatments and the highest was found at the $d_{100}$ (Table 6). There was no difference between the two growing seasons (Table 4).

Stomatal conductance to water vapour $\left(\mathrm{g}_{\mathrm{s}}\right)$ showed a different trend than the assimilation rate as it was affected by all the factors that were studied and also by the genotype and year, irrigation and year and growth stage and year. The differences for the cultivars were not significant at the end of flowering but there were differences for the irrigation treatments (Table 4).

Evapotranspiration rate (E) was affected by all the factors that were studied and also by the $G \times Y$, $\mathrm{W} \times \mathrm{Y}$ and $\mathrm{S} \times \mathrm{Y}$. E was higher at $\mathrm{d}_{100}$ and lower at $\mathrm{d}_{40}$ and it was higher at 2015. Mrs Burns and Cinnamon had the highest $\mathrm{E}$ at the beginning of flowers and lower at Sweet. It was higher at Mrs Burns and lower at Sweet at the beginning of flowers, also it was higher at $d_{100}$ and lower at $d_{40}$ and higher at 2015 compared with the 2016. Similar was the trend for Cinnamon at full bloom with the difference at Cinnamon that had the highest values (Table 4).

Intercellular $\mathrm{CO}_{2}$ concentration $\left(\mathrm{C}_{\mathrm{i}}\right)$ was affected by growth stages, year, genotypes and the interaction of genotypes and year, growth stages and years, genotypes and growth stages, genotypes, years and growth stages and the four way interactions of growth stages, genotypes, irrigation and years. $C_{i}$ was higher at Mrs Burns and Cinnammon at beginning of flowering and at full bloom and it was higher at $d_{100}$ at full bloom and end of flowering and also at end of flowering Thai showed the highest $C_{\mathrm{i}}$ (Table 4).

Instantaneous WUE was affected by growth stages, year, irrigation, cultivar, and by the interactions between cultivars and years, growth stages and years, cultivars and growth stages, and by the interaction of cultivars, years and growth stages. WUE was higher at the $d_{40}$ treatment and lower at the $d_{100}$ treatment (Table 4). The lowest WUE was found at Mrs Burns cultivar, followed by Cinnamon, and the higher was found at Sweet. The trend was similar in all cultivars, and the lowest WUE was found at the $\mathrm{d}_{100}$ treatment and at 2015 .

\subsection{Chlorophyll Fluorescence}

Quantum efficiency of photosystem (PS) II was affected by growth stage and genotype and also by the interaction between genotype and year, growth stages and year, genotype and growth stages and the three way interaction genotype, year and growth stage. There were no differences among the five cultivars at the first two growth stages but at the end of flowering Mrs Burns and Cinammon showed the highest quantum yield and followed by Sweet, the lowest quantum yield was found at Thai and Red Rubin (Tables 2, 5 and 6). 
Table 4. Combined effect of Years $(2015,2016)$, Cultivars, Irrigation levels and Stages of development on Stomatal conductance, Evapotranspiration, Internal leaf $\mathrm{CO}_{2}$ concentration and Intrinsic Water use efficiency. Data presented are mean values, where LSD is the least significant difference at the 0.05 significance level.

\begin{tabular}{|c|c|c|c|c|c|c|c|c|c|c|}
\hline \multirow{2}{*}{ Cultivars } & \multirow{2}{*}{$\begin{array}{l}\text { Irrigation } \\
\text { Treatment }\end{array}$} & \multirow[t]{2}{*}{ Stage } & \multicolumn{2}{|c|}{ Stomatal Conductance } & \multicolumn{2}{|c|}{ Evapotranspiration } & \multicolumn{2}{|c|}{$\begin{array}{c}\text { Internal Leaf } \mathrm{CO}_{2} \\
\text { Concentration }\end{array}$} & \multicolumn{2}{|c|}{$\begin{array}{l}\text { Intrinsic Water Use } \\
\text { Efficiency }\end{array}$} \\
\hline & & & 2015 & 2016 & 2015 & 2016 & 2015 & 2016 & 2015 & 2016 \\
\hline \multirow{7}{*}{ Mrs Burns } & $\mathrm{d}_{40}$ & \multirow{3}{*}{$\begin{array}{l}\text { Beginning of } \\
\text { flowering }\end{array}$} & 0.47 & 0.15 & 5.07 & 3.57 & 361.97 & 220.47 & 4.36 & 58.94 \\
\hline & $\mathrm{d}_{100}$ & & 0.45 & 0.17 & 5.59 & 3.17 & 357.13 & 207.83 & 13.17 & 60.88 \\
\hline & $\mathrm{d}_{40}$ & & 0.25 & 0.10 & 3.49 & 1.75 & 288.61 & 188.93 & 39.24 & 94.21 \\
\hline & $\mathrm{d}_{70}$ & \multirow{2}{*}{ Full bloom } & 0.19 & 0.12 & 3.25 & 2.46 & 264.02 & 248.94 & 47.27 & 77.47 \\
\hline & $\mathrm{d}_{100}$ & & 0.34 & 0.13 & 4.85 & 2.81 & 246.69 & 202.87 & 36.10 & 103.51 \\
\hline & $\mathrm{d}_{70}$ & \multirow{2}{*}{$\begin{array}{l}\text { End of } \\
\text { flowering }\end{array}$} & 0.24 & 0.14 & 4.72 & 3.23 & 247.28 & 180.67 & 51.72 & 83.35 \\
\hline & $\mathrm{d}_{100}$ & & 0.31 & 0.16 & 6.04 & 2.52 & 264.97 & 232.08 & 42.29 & 86.31 \\
\hline \multirow{7}{*}{ Cinnamon } & $\mathrm{d}_{40}$ & \multirow{3}{*}{$\begin{array}{l}\text { Beginning of } \\
\text { flowering }\end{array}$} & 0.48 & 0.09 & 5.33 & 2.22 & 356.27 & 235.20 & 5.45 & 59.93 \\
\hline & $\mathrm{d}_{70}$ & & 0.36 & 0.21 & 5.15 & 4.23 & 344.20 & 233.03 & 13.62 & 47.43 \\
\hline & $\mathrm{d}_{100}$ & & 0.33 & 0.16 & 5.31 & 3.84 & 356.72 & 233.63 & 11.05 & 54.36 \\
\hline & $\mathrm{d}_{40}$ & \multirow{3}{*}{ Full bloom } & 0.19 & 0.11 & 2.79 & 1.94 & 274.89 & 183.82 & 49.94 & 88.22 \\
\hline & $d_{70}$ & & 0.24 & 0.16 & 3.67 & 2.75 & 276.95 & 225.09 & 37.78 & 65.09 \\
\hline & $\mathrm{d}_{100}$ & & 0.42 & 0.19 & 5.30 & 2.85 & 266.67 & 227.93 & 29.59 & 74.89 \\
\hline & $\mathrm{d}_{40}$ & $\begin{array}{l}\text { End of } \\
\text { flowering }\end{array}$ & 0.11 & 0.10 & 2.57 & 2.78 & 218.06 & 195.00 & 131.48 & 81.87 \\
\hline \multirow{9}{*}{ Sweet } & $\mathrm{d}_{40}$ & \multirow{4}{*}{$\begin{array}{l}\text { Beginning of } \\
\text { flowering }\end{array}$} & 0.15 & 0.16 & 2.70 & 2.54 & 240.03 & 180.07 & 67.82 & 68.58 \\
\hline & $\mathrm{d}_{70}$ & & 0.18 & 0.20 & 3.52 & 3.17 & 243.88 & 218.40 & 59.00 & 54.77 \\
\hline & $\mathrm{d}_{100}$ & & 0.34 & 0.20 & 4.98 & 2.83 & 234.61 & 244.90 & 46.12 & 62.12 \\
\hline & $\mathrm{d}_{40}$ & & 0.07 & 0.15 & 2.30 & 3.56 & 144.17 & 183.73 & 166.87 & 75.07 \\
\hline & $\mathrm{d}_{70}$ & \multirow{2}{*}{ Full bloom } & 0.10 & 0.14 & 2.65 & 3.31 & 153.45 & 192.73 & 106.55 & 78.34 \\
\hline & $\mathrm{d}_{100}$ & & 0.09 & 0.17 & 2.73 & 2.54 & 144.56 & 231.27 & 144.85 & 65.41 \\
\hline & $\mathrm{d}_{40}$ & \multirow{3}{*}{$\begin{array}{c}\text { End of } \\
\text { flowering }\end{array}$} & 0.11 & 0.10 & 2.45 & 2.73 & 252.11 & 170.37 & 116.78 & 94.50 \\
\hline & $\mathrm{d}_{70}$ & & 0.17 & 0.10 & 3.50 & 2.55 & 293.28 & 158.33 & 50.02 & 102.43 \\
\hline & $\mathrm{d}_{100}$ & & 0.11 & 0.25 & 3.05 & 4.08 & 237.28 & 226.60 & 99.18 & 55.34 \\
\hline
\end{tabular}


Table 4. Cont.

\begin{tabular}{|c|c|c|c|c|c|c|c|c|c|c|}
\hline \multirow{2}{*}{ Cultivars } & \multirow{2}{*}{$\begin{array}{l}\text { Irrigation } \\
\text { Treatment }\end{array}$} & \multirow{2}{*}{ Stage } & \multicolumn{2}{|c|}{ Stomatal Conductance } & \multicolumn{2}{|c|}{ Evapotranspiration } & \multicolumn{2}{|c|}{$\begin{array}{c}\text { Internal Leaf } \mathrm{CO}_{2} \\
\text { Concentration }\end{array}$} & \multicolumn{2}{|c|}{$\begin{array}{l}\text { Intrinsic Water Use } \\
\text { Efficiency }\end{array}$} \\
\hline & & & 2015 & 2016 & 2015 & 2016 & 2015 & 2016 & 2015 & 2016 \\
\hline \multirow{9}{*}{ Red Rubin } & $\mathrm{d}_{40}$ & \multirow{4}{*}{$\begin{array}{l}\text { Beginning of } \\
\text { flowering }\end{array}$} & 0.23 & 0.12 & 3.17 & 2.25 & 298.67 & 209.99 & 38.03 & 69.08 \\
\hline & $\mathrm{d}_{70}$ & & 0.33 & 0.16 & 4.45 & 2.42 & 299.83 & 212.35 & 27.73 & 69.13 \\
\hline & $\mathrm{d}_{100}$ & & 0.42 & 0.15 & 5.68 & 2.17 & 274.83 & 256.27 & 23.98 & 70.48 \\
\hline & $\mathrm{d}_{40}$ & & 0.07 & 0.18 & 1.94 & 3.74 & 164.22 & 191.93 & 138.14 & 64.44 \\
\hline & $\mathrm{d}_{70}$ & \multirow{2}{*}{ Full bloom } & 0.12 & 0.24 & 2.69 & 4.39 & 207.11 & 248.40 & 95.60 & 58.44 \\
\hline & $\mathrm{d}_{100}$ & & 0.28 & 0.24 & 4.40 & 2.58 & 244.53 & 291.27 & 49.11 & 50.13 \\
\hline & $\mathrm{d}_{40}$ & \multirow{3}{*}{$\begin{array}{l}\text { End of } \\
\text { flowering }\end{array}$} & 0.10 & 0.17 & 2.62 & 3.74 & 182.22 & 197.67 & 139.56 & 68.68 \\
\hline & $\mathrm{d}_{70}$ & & 0.10 & 0.23 & 2.83 & 4.01 & 216.78 & 236.20 & 109.85 & 51.94 \\
\hline & $\mathrm{d}_{100}$ & & 0.15 & 0.18 & 3.43 & 3.31 & 257.56 & 190.62 & 69.61 & 80.02 \\
\hline \multirow{9}{*}{ Thai } & $\mathrm{d}_{40}$ & \multirow{4}{*}{$\begin{array}{l}\text { Beginning of } \\
\text { flowering }\end{array}$} & 0.23 & 0.15 & 3.16 & 2.14 & 296.64 & 193.53 & 38.41 & 83.36 \\
\hline & $\mathrm{d}_{70}$ & & 0.36 & 0.32 & 4.01 & 3.25 & 302.75 & 239.00 & 25.87 & 52.42 \\
\hline & $\mathrm{d}_{100}$ & & 0.37 & 0.23 & 5.21 & 3.37 & 250.11 & 199.23 & 42.64 & 68.16 \\
\hline & $\mathrm{d}_{40}$ & & 0.05 & 0.13 & 1.80 & 3.02 & 153.22 & 200.72 & 161.11 & 69.62 \\
\hline & $\mathrm{d}_{70}$ & \multirow{2}{*}{ Full bloom } & 0.10 & 0.15 & 2.55 & 3.33 & 187.61 & 186.54 & 88.60 & 83.11 \\
\hline & $\mathrm{d}_{100}$ & & 0.15 & 0.17 & 3.57 & 2.48 & 209.44 & 263.67 & 61.84 & 61.06 \\
\hline & $\mathrm{d}_{40}$ & \multirow{3}{*}{$\begin{array}{l}\text { End of } \\
\text { flowering }\end{array}$} & 0.09 & 0.13 & 2.02 & 2.72 & 388.89 & 213.73 & 70.24 & 76.42 \\
\hline & $\mathrm{d}_{70}$ & & 0.09 & 0.26 & 2.66 & 4.10 & 185.69 & 252.73 & 121.93 & 48.00 \\
\hline & $\mathrm{d}_{100}$ & & 0.17 & 0.24 & 3.96 & 4.16 & 257.22 & 228.82 & 54.11 & 58.13 \\
\hline $\mathrm{LSD}_{0.05}$ & & & 0.12 & 0.12 & 1.39 & 1.39 & 63.39 & 63.39 & 34.99 & 34.99 \\
\hline $\mathrm{CV} \%$ & & & 43.1 & & 29.5 & & 19.4 & & 36.4 & \\
\hline
\end{tabular}

Table 5. Combined effect of Years $(2015,2016)$, Cultivars and Stages of development on Chlorophyll Fluorescence and Assimilation rate $\mathrm{CO}_{2}$. Data presented are mean values, where LSD is the least significant difference at the 0.05 significance level.

\begin{tabular}{|c|c|c|c|c|c|c|c|}
\hline \multirow{3}{*}{ Cultivars } & \multirow{3}{*}{ Stage } & \multicolumn{2}{|c|}{ Chlorophyll Fluorescence } & \multicolumn{4}{|c|}{ Assimilation Rate $\mathrm{CO}_{2}$} \\
\hline & & \multirow{2}{*}{2015} & \multirow{2}{*}{2016} & \multicolumn{2}{|c|}{2015} & \multicolumn{2}{|c|}{2016} \\
\hline & & & & Transformed $^{1}$ & Actual $^{2}$ & Transformed $^{1}$ & Actual $^{2}$ \\
\hline \multirow{3}{*}{ Mrs Burns } & Beginning of flowering & 0.65 & 0.72 & 0.57 & 3.64 & 0.99 & 9.63 \\
\hline & Full bloom & 0.75 & 0.65 & 1.03 & 10.30 & 1.03 & 10.34 \\
\hline & End of flowering & 0.73 & 0.64 & 1.09 & 11.55 & 1.00 & 9.53 \\
\hline
\end{tabular}


Table 5. Cont.

\begin{tabular}{|c|c|c|c|c|c|c|c|}
\hline \multirow{3}{*}{ Cultivars } & \multirow{3}{*}{ Stage } & \multicolumn{2}{|c|}{ Chlorophyll Fluorescence } & \multicolumn{4}{|c|}{ Assimilation Rate $\mathrm{CO}_{2}$} \\
\hline & & \multirow{2}{*}{2015} & \multirow{2}{*}{2016} & \multicolumn{2}{|c|}{2015} & \multicolumn{2}{|c|}{2016} \\
\hline & & & & Transformed $^{1}$ & Actual $^{2}$ & Transformed $^{1}$ & Actual $^{2}$ \\
\hline \multirow{3}{*}{ Cinnamon } & Beginning of flowering & 0.62 & 0.76 & 0.62 & 3.68 & 0.90 & 7.50 \\
\hline & Full bloom & 0.70 & 0.64 & 1.02 & 9.71 & 1.06 & 10.87 \\
\hline & End of flowering & 0.73 & 0.67 & 1.16 & 14.02 & 0.95 & 8.32 \\
\hline \multirow{3}{*}{ Sweet } & Beginning of flowering & 0.74 & 0.64 & 1.08 & 11.24 & 1.08 & 11.45 \\
\hline & Full bloom & 0.73 & 0.66 & 1.07 & 11.07 & 1.06 & 10.54 \\
\hline & End of flowering & 0.59 & 0.61 & 1.01 & 9.69 & 1.07 & 11.02 \\
\hline \multirow{3}{*}{ Red Rubin } & Beginning of flowering & 0.67 & 0.67 & 1.00 & 9.60 & 1.00 & 9.38 \\
\hline & Full bloom & 0.72 & 0.68 & 1.03 & 10.07 & 1.07 & 11.04 \\
\hline & End of flowering & 0.54 & 0.62 & 1.06 & 10.87 & 1.10 & 11.68 \\
\hline \multirow{3}{*}{ Thai } & Beginning of flowering & 0.69 & 0.63 & 1.02 & 10.31 & 1.11 & 12.41 \\
\hline & Full bloom & 0.73 & 0.67 & 0.98 & 8.81 & 1.04 & 10.04 \\
\hline & End of flowering & 0.57 & 0.61 & 0.97 & 8.70 & 1.08 & 11.39 \\
\hline $\mathrm{LSD}_{0.05}$ & & 0.04 & 0.04 & 0.11 & & 0.11 & \\
\hline $\mathrm{CV} \%$ & & 6.7 & & 31.2 & & & \\
\hline
\end{tabular}

${ }^{1}$ Data presented in column titled "Transformed" are means of $\log _{10}(X+1)$ transformed values. ${ }^{2}$ Values in column titled "Actual" correspond to the means computed from raw data.

Table 6. Main effect of Irrigation levels on Assimilation rate $\mathrm{CO}_{2}$. Data presented are mean values, where LSD is the least significant difference at the 0.05 significance level.

\begin{tabular}{ccc}
\hline \multirow{2}{*}{ Irrigation Treatment } & \multicolumn{2}{c}{ Assimilation Rate $\mathbf{C O}_{\mathbf{2}}$} \\
\cline { 2 - 3 } & Transformed $^{\mathbf{1}}$ & Actual $^{\mathbf{2}}$ \\
\hline $\mathrm{d}_{40}$ & 0.96 & 8.86 \\
$\mathrm{~d}_{70}$ & 1.01 & 9.90 \\
$\mathrm{~d}_{100}$ & 1.05 & 11.08 \\
$\mathrm{LSD}_{0.05}$ & 0.05 & \\
$\mathrm{CV} \%$ & 31.6 & \\
\hline
\end{tabular}

${ }^{1}$ Data presented in column titled "Transformed" are means of $\log _{10}(X+1)$ transformed values. ${ }^{2}$ Values in column titled "Actual" correspond to the means computed from raw data. 


\subsection{Dry Herb Yield}

Dry weight of herbal material was affected by cultivar, irrigation treatments, growth stage, year, cultivars, and by the interactions of cultivars with years and growth stages (Table 2 and Figure 1). Mrs Burns and Cinnamon showed increase in dry weight of herbal material from the initiation of flowering to full bloom. In 2015, the herbal weight of 'Mrs Burns' remained stable from full bloom to the end of flowering while in 'Cinnamon' was increased. However, in 2016, both 'Mrs Burns' and 'Cinnamon' showed an increase in herbal weight from the beginning of flowering up to the end of flowering. For the cultivar Sweet and Red Rubin, there was an increase in the dry weight from the first stage to the second growth stage, and then there was a decrease from the second to the third for Sweet and no difference for Red Rubin. In contrast, Thai cultivar did not show any significant response between the three growth stages.
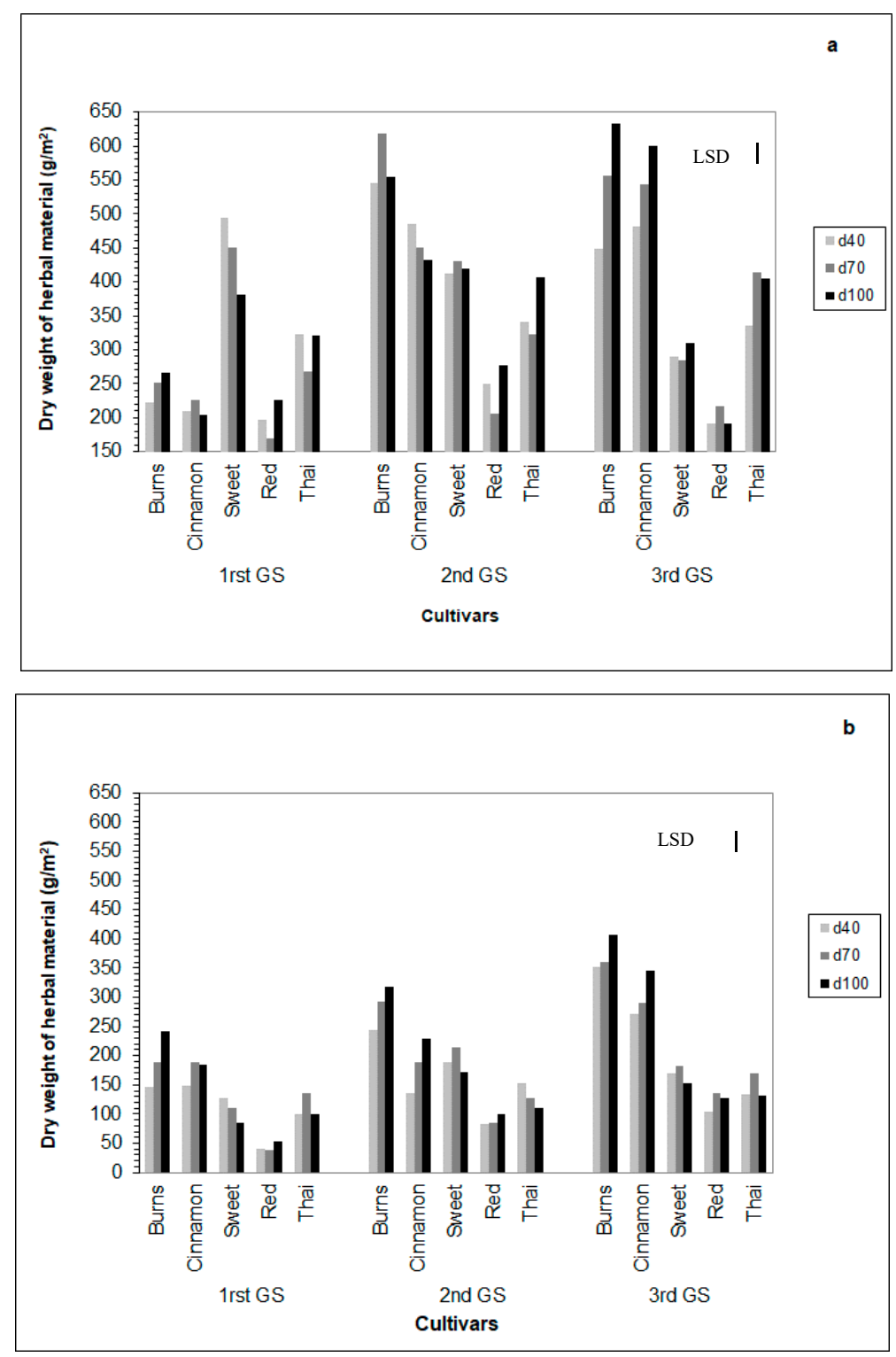

Figure 1. Dry weight of herbal material of the five basil cultivars during the three growing stages (GS) (where 1 is for the initiation of flowering, 2 is for the full bloom, 3 is the end of flowering) at the three irrigation levels $\left(d_{40}, d_{70}\right.$ and $\left.d_{100}\right)$ for the two growing seasons 2015 (a) and 2016 (b). Data presented are mean values; vertical bar corresponds to the least significant difference (LSD $=85.89$ ). 


\subsection{Essential Oil Content}

Essential oil content was affected by growth stages, irrigation, cultivar, and also by their interactions. However, it was not affected by year and the two-way interactions of irrigation with other factors. The highest essential oil content was found at Mrs Burns cultivar, followed by Cinnamon and Thai. The lowest essential oil content was found at Red Rubin (Figure 2). The growth stage that showed the lowest essential oil content was at the end of flowering for both growing seasons. When there was a reduction in water availability there was also a reduction in essential oil content in most cases.

a

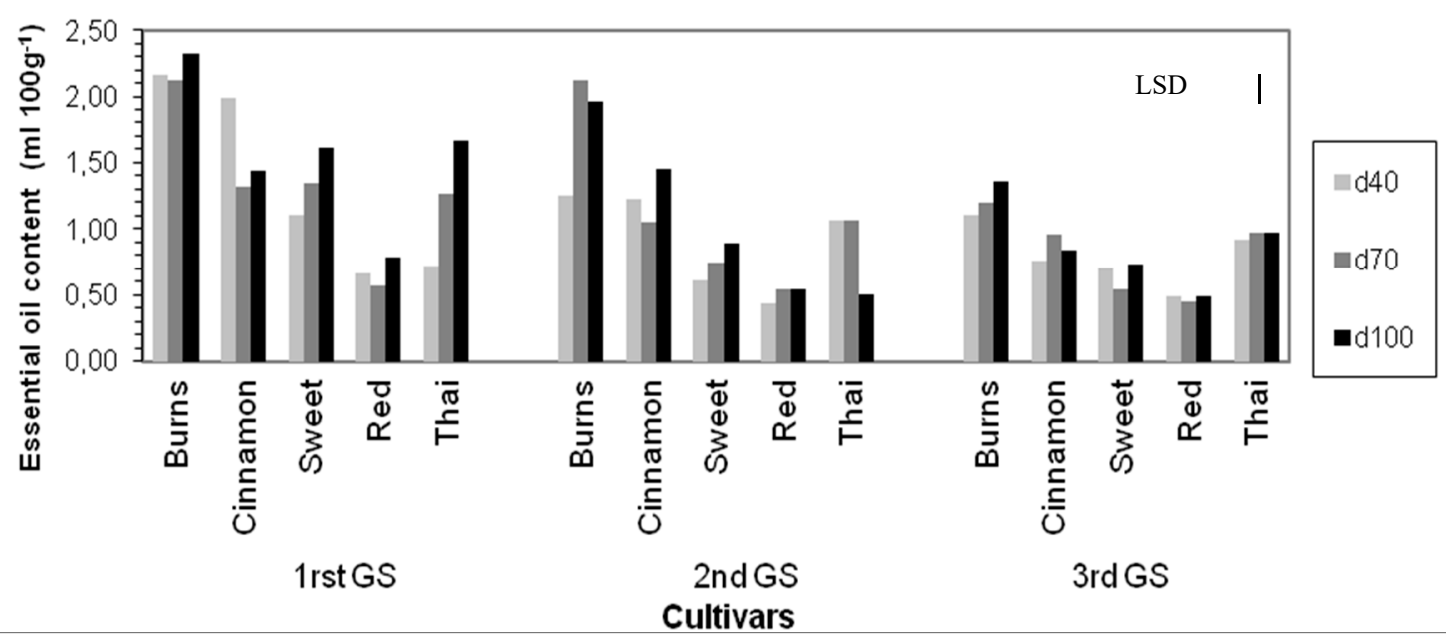

b

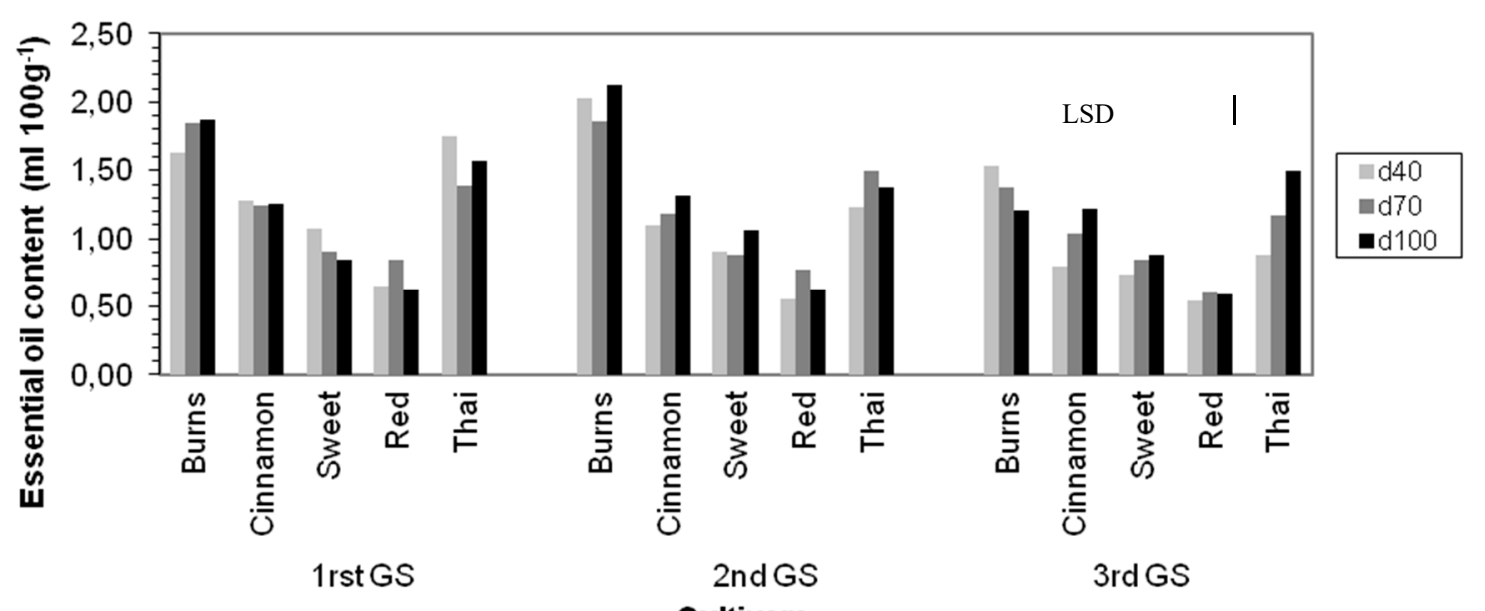

Figure 2. Essential oil content of the five basil cultivars during the three growing stages (GS) (where 1 is for the initiation of flowering, 2 is for the full bloom, 3 is the end of flowering) at the three irrigation levels $\left(d_{40}, d_{70}\right.$ and $\left.d_{100}\right)$ for the two growing seasons 2015 (a) and $2016(\mathbf{b})$. Data presented are mean values; vertical bar corresponds to the least significant difference (LSD $=0.41$ ).

\section{Discussion}

\subsection{Chlorophyll Content}

Chlorophyll content determined with a chlorophyll meter e.g., SPAD has been proposed as a good indicator of green color and the stay green characteristic in several plant species and also for stress 
tolerance index $[29,30]$. However, in basil it was not affected by the irrigation but it was affected by the cultivar. These results indicate that chlorophyll content cannot be used as selection criteria for of tolerant cultivars to water stress. In other plant species it was found that chlorophyll content can be used under water stress [20,43].

\subsection{Leaf Temperature}

Leaf temperature is a reliable index for water stress for many crop species [20,44]. A value of leaf temperature above $3{ }^{\circ} \mathrm{C}$ the ambient temperature can be used as a threshold indicating non-stress water conditions in basil during anthesis and allowing growers to schedule irrigation [43].

\subsection{Water Potential}

Leaf water potential declined in all treatments in response to the reduction to lower irrigation. The leaf water potential had in some cases very low values up to $-15 \mathrm{MP}_{\mathrm{a}}$ which was lower compared with $-3.63 \mathrm{MP}_{\mathrm{a}}$ at the $\mathrm{d}_{100}$. Thus, at a given level of water availability the leaf water potential was lower than at the $d_{40}$ compared with the other two treatments. When plants are exposed to water stress leaf water potential is lowered, which affects negatively plant metabolic activity over time [45]. Similar response was found in other plant species and leaf water potential has been proposed to be used as a marker for water stress [20,45].

\subsection{Gas-Exchange Measurements}

The effect of water stress on physiological characteristics of most crop plants has been studied extensively $[18,45,46]$, but it was not studied in aromatic and medicinal plants were the last years there is an increased interest. The reduction in photosynthetic efficiency is a well-known symptom of water stress and has been observed in many plant species [22-25,33,45]. In the present study a reduction of the assimilation rate was observed in most cultivars after exposure to drought. This reduction was usually accompanied with a decrease in $\mathrm{g}_{\mathrm{s}}$ and $\mathrm{E}$ (data not shown). However, the cultivar Mrs Burns did not show any changes of stomatal function or even displayed an increased $g_{s}$ under drought compared with the nonstressed plants and in this case there was also an increase in $\mathrm{E}$ and $\mathrm{A}$. When the plants are exposed to water stress stomata closes and there is a reduction in $\mathrm{E}$ and also in A. In addition, as water deficit persists for longer period there is a higher reduction in A [44,47-49]. When the stomata close there is a decrease in $\mathrm{g}_{\mathrm{s}}$ and also a reduction in A under water deficit $[40,50,51]$.

The use of physiological traits in aromatic and medicinal plants was not explored and can be used to help in the improvement of water stress tolerance of genotypes. However, these traits have to fulfill several criteria as they have to be simple and the measurements should be fast and there should be a good correlation with tolerance, and should be adequate interspecific genetic variation $[18,33,34]$. The physiological traits that were studied can satisfy the first condition (particularly the Chl fluorescence measurements) and more-or-less meet also the second condition (based on the presence of positive correlations between $\mathrm{Chl}$ fluorescence and dry herb yield). In other studies it was reported that there is correlation of tolerance and chlorophyll fluorescence [26] or Chl content [44].

The significant variability of the physiological characteristics that are used in this study were reported in other studies [20]. Therefore, these parameters can be used for the selection tolerant basil cultivars to water stress.

\subsection{Chlorophyll Fluorescence}

The maximum quantum efficiency of PSII photochemistry was used as an index for stress tolerance and especially for water stress [20,29,30,50], however it was not used in aromatic and medicinal plants and especially in basil. Similar values for basil of quantum yield efficiency were reported by others [51] but it was not determined under stress conditions and under field conditions. It was reported by others that primary photosynthetic reactions such as photosynthetic electron transport are rather resilient to water stress, and when there is a reduction in photosynthetic electron transport efficiency occurs 
after there is an imbalance between the generation of NADPH and its utilization in the photosynthetic carbon reduction cycle [44]. Under water stress there is a significant increase in generation of reactive oxygen species which leads to photooxidation and the degradation of photosynthetic membrane proteins and more specifically $\mathrm{D}_{1}, \mathrm{D}_{2}$ and CP43 proteins of PSII and the associated pigments and lipids $[47,48]$. However, in the present study there was no significant effect on the irrigation treatments but only on the growth stages, cultivars and years.

\subsection{Dry Herb Yield}

The dry herb yield is the most important product together with the essential oil content of aromatic and medicinal plants, therefore is important to have high yield with increased content of essential oils. The dry herb yield was also affected by the irrigation treatments, growth stages, year, and cultivars. The cultivar that showed the highest dry herb weight was Mrs Burns in both years. The lowest dry herb yield was found at Red Rubin for both years. Dry herb yield was lower under water stress and this can be due to lowering the leaf area index [5] and the reduction in photosynthesis [15,52-54]. The growth stage that water stress had the highest effect was at the end of flowering.

The dry herb yield was relatively high and varied from $37 \mathrm{~g} / \mathrm{m}^{2}$ to $495 \mathrm{~g} / \mathrm{m}^{2}$ and most cultivars having yields greater than the dry herb yield reported in other studies $[11,14,15]$. The dry herb yield variation that was found reflects different genetic backgrounds of the cultivars that were used in this study and similar response was found by others using a number of different genotypes $[11,16,45,49]$. Most of the cultivars had yield greater than $100 \mathrm{~g} / \mathrm{m}^{2}$ which is considered very high. These data suggest that most of the cultivars that were used can provide high dry herb yield under Mediterranean conditions and can be adapted by the farmers.

\subsection{Essential Oil Content}

Essential oil content is a characteristic that can be affected by genotype, growing conditions, growth stage etc. $[11,16,45,55]$. In the present study essential oil content was affected by the irrigation level. Water stress can positive or negative effect of on essential oil content as it was reported in other species $[16,17,56,57]$. It was found a great variation in the essential oil content among the cultivars that were used as it ranged from 0.45 up to $2.33 \mathrm{~mL} 100 \mathrm{~g}^{-1}$ and depended from the growth stage, cultivar, year and irrigation level. Most of the cultivars had essential oil content higher than the oil content

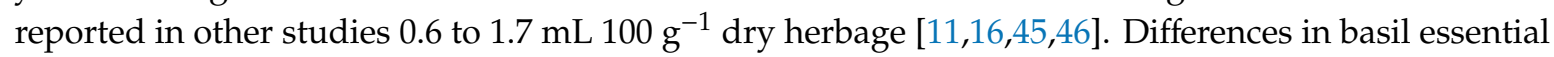
oil content between the present and other studies could be due to differential environmental conditions and genetic material that were used. It was reported that basil essential oil content can vary depending on growth conditions [7,45]. The findings from this study are important in two ways: (1) basil can be used for high essential oil production and (2) most of the cultivars can be used for high dry herb yield.

\section{Conclusions}

The use of physiological characteristics such as chlorophyll fluorescence, water potential, E, $\mathrm{g}_{\mathrm{s}}$ and $\mathrm{A} / \mathrm{g}_{\mathrm{s}}$ together with the dry herb yield can be used for the selection of basil cultivars under control and water stress conditions. Also cultivar Mrs Burns showed to be more tolerant to water stress and can be used in limited water environments. In addition, $70 \%$ of ET seems that does not affect significantly yield and essential oil content and under water limited environments we can reduce the amount of irrigation water. However, for higher essential oil content there is a need to screen genotypes under field conditions and at different environments as essential oil content was not correlated with any of physiological characteristics that were studied.

Author Contributions: All the authors have contributed on the manuscript significantly. I.K. conducted the experiments. P.G. took care of the water treatments and analysis of results related with the water treatments. G.M. was responsible for the statistical analysis. C.D. was responsible for conducting the experiment and also writing the manuscript. All authors have read and agreed to the published version of the manuscript.

Funding: This research received no external funding. 
Acknowledgments: We are grateful to Anastasios Lithourgidis and the personnel of the University Farm of the Aristotle University of Thessaloniki for assistance with the field experiments.

Conflicts of Interest: The authors declare no conflict of interest.

\section{References}

1. Parry, M.A.J.; Flexas, J.; Medrano, H. Prospects for crop production under drought: Research priorities and future directions. Ann. Appl. Biol. 2005, 147, 211-226. [CrossRef]

2. Debaeke, P.; Aboudrare, A. Adaptation of crop management to water-limited environments. Europ. J. Agron. 2004, 21, 433-446. [CrossRef]

3. Jacobsen, S.E.; Jensen, C.R.; Liu, F. Improving crop production in the arid Mediterranean climate. Field Crops Res. 2012, 128, 34-47. [CrossRef]

4. Blum, A. Plant Breeding for Water-Limited Environments; Springer: New York, NY, USA; Dordrecht, The Netherlands; Heidelberg, Germany; London, UK, 2011; ISBN 978-1-4419-7490-7. [CrossRef]

5. Kalamartzis, I.; Dordas, C.; Georgiou, P.; Menexes, G. The Use of Appropriate Cultivar of Basil (Ocimum basilicum) Can Increase Water Use Efficiency under Water Stress. Agronomy 2020, 10, 70. [CrossRef]

6. Darrah, H.H. The Cultivated Basils; Buckeye Printing Company, Independence: St. Louis, MO, USA, 1988.

7. Simon, J.E.; Quinn, J.; Murray, R.G. Basil: A Source of Essential Oils. In Advances in New Crops; Janick, J., Simon, J.E., Eds.; Timber Press: Portland, OR, USA, 1990; pp. 484-489.

8. Carovic-Stanko, K.; Liber, Z.; Besendorfer, V.; Javornik, B.; Bohanec, B.; Kolak, I.; Satovic, Z. Genetic relations among basil taxa (Ocimum L.) based on molecular markers, nuclear DNA content, and chromosome number. Plant Syst. Evol. 2010, 285, 13-22. [CrossRef]

9. Makri, O.; Kintzios, S. Ocimum sp. (basil): Botany, cultivation, pharmaceutical properties, and biotechnology. J. Herbs Spices Med. Plants 2007, 13, 123-150. [CrossRef]

10. Juliani, H.R.; Simon, J.E. Antioxidant activity of basil. In Trends in New Crops and New Uses; Janic, J., Whipkey, A., Eds.; ASHS Press: Alexandria, VA, USA, 2002; pp. 575-579.

11. Ekren, S.; Sönmez, C.; Özcakal, E.; Kurttas, Y.S.K.; Bayram, E.; Gürgülü, H. The effect of different irrigation water levels on yield and quality characteristics of purple basil (Ocimum basilicum L.). Agric. Water Manag. 2012, 109, 155-161. [CrossRef]

12. Yassen, M.; Ram, P.; Anju, Y.; Singh, K. Response of Indian basil (Ocimum basilicum L.) to irrigation and nitrogen schedule in Central Uttar Pradesh. Ann. Plant Physiol. 2003, 17, 177-181.

13. Omidbaigi, R.; Hassani, A.; Sefidkon, F. Essential oil content and composition of sweet basil (Ocimum basilicum L.) at different irrigation regimes. J. Ess. Oil Bear. Plants 2003, 6, 104-108. [CrossRef]

14. Singh, M. Effect of nitrogen and irrigation on the yield and quality of sweet basil (Ocimum basilicum L.). J. Spices Aromat. Crops 2003, 11, 151-154.

15. Khalid, K.A. Influence of water stress on growth, essential oil and chemical composition of herbs (Ocimum sp.). Int. Agrophys. 2006, 20, 289-296.

16. Asadollahi, A.; Mirza, M.; Abbaszadeh, B.; Azizpour, S.; Keshavarzi, A. Comparison of Essential oil from Leaves and Inflorescence of three Basil (Ocimum basilicum L.). Populations under Drought Stress. Int. J. Agron. Plant Prod. 2013, 4, 2764-2767.

17. Kulak, M.; Ozkan, A.; Bindak, R. A bibliometric analysis of the essential oil-bearing plants exposed to the water stress: How long way we have come and how much further? Sci. Hortic. 2019, 246, 418-436. [CrossRef]

18. Brennan, J.P.; Martin, P.J. Returns to investment in new breeding technologies. Euphytica 2007, 157, 337-349. [CrossRef]

19. Lawlor, D.W. Genetic engineering to improve plant performance under drought: Physiological evaluation of achievements, limitations, and possibilities. J. Exper. Bot. 2013, 64, 83-108. [CrossRef] [PubMed]

20. Dordas, C.; Papathanasiou, F.; Lithourgidis, A.; Petrevska, J.K.; Papadopoulos, I.; Pankou, C.; Gekas, F.; Ninou, E.; Mylonas, I.; Sistanis, I.; et al. Evaluation of physiological characteristics as selection criteria for drought tolerance in maize inbred lines and their hybrids. Maydica 2018, 63, 1-14.

21. Ober, E.S.; Le Bloa, M.; Clark, C.J.A.; Royal, A.; Jaggard, K.W.; Pidgeon, J.D. Evaluation of physiological traits as indirect selection criteria for drought tolerance in sugar beet. Field Crops Res. 2005, 91, 231-249. [CrossRef] 
22. Subrahmanyam, D.; Subash, N.; Haris, A.; Sikka, A.K. Influence of water stress on leaf photosynthetic characteristics in wheat cultivars differing in their susceptibility to drought. Photosynthetica 2006, 44, 125-129. [CrossRef]

23. Khan, H.U.R.; Link, W.; Hocking, T.J.; Stoddard, F.L. Evaluation of physiological traits for improving drought tolerance in faba bean (Vicia faba L.). Plant Soil 2007, 292, 205-217. [CrossRef]

24. Hura, T.; Grzesiak, S.; Hura, K.; Thiemt, E.; Tokarz, K.; Wędzony, M. Physiological and biochemical tools useful in drought-tolerance detection in genotypes of winter triticale: Accumulation of ferulic acid correlates with drought tolerance. Ann. Bot. 2007, 100, 767-775. [CrossRef] [PubMed]

25. Tribulato, A.; Toscano, S.; Di Lorenzo, V.; Romano, D. Effects of Water Stress on Gas Exchange, Water Relations and Leaf Structure in Two Ornamental Shrubs in the Mediterranean Area. Agronomy 2019, 9, 381. [CrossRef]

26. Sánchez-Reinoso, A.D.; Ligarreto-Moreno, G.A.; Restrepo-Díaz, H. Chlorophyll Fluorescence Parameters as an Indicator to Identify Drought Susceptibility in Common Bush Bean. Agronomy 2019, 9, 526. [CrossRef]

27. Ahmed, H.G.M.-D.; Li, S.M.; Azmat, M.A.; Rizwan, M.; Maqsood, R.H.; Khan, S.H. Selection Criteria for Drought-Tolerant Bread Wheat Genotypes at Seedling Stage. Sustainability 2019, 11, 2584. [CrossRef]

28. Puglisi, I.; Nicolosi, E.; Vanella, D.; Piero, A.R.L.; Stagno, F.; Saitta, D.; Roccuzzo, G.; Consoli, S.; Baglieri, A. Physiological and Biochemical Responses of Orange Trees to Dierent Deficit Irrigation Regimes. Plants 2019, 10, 423.

29. Li, R.H.; Guo, P.G.; Baum, M.; Grando, S.; Ceccarelli, S. Evaluation of chlorophyll content and fluorescence parameters as indicators of drought tolerance in barley. Agric. Sci. China 2006, 5, 751-757. [CrossRef]

30. Fotovat, R.; Valizadeh, M.; Toorchi, M. Association between water-use efficiency components and total chlorophyll content (SPAD) in wheat (Triticum aestivum L.) under well-watered and drought stress conditions. J. Food Agric. Environ. 2007, 5, 225-227.

31. Silva, M.A.; Jifon, J.L.; Da Silva, J.A.G.; Sharma, V. Use of physiological parameters as fast tools to screen for drought tolerance in sugarcane-Braz. J. Plant Physiol. 2007, 19, 193-201.

32. Royo, C.; García del Moral, L.F.; Aparicio, N.; Villegas, D.; Casadesús, J.; Araus, J.L. Tools for improving the efficiency of durum wheat selection under Mediterranean conditions. In Seminar on Durum Wheat Improvement in the Mediterranean Region; New Challenges: Zaragoza, Spain, 2000; pp. 63-70.

33. O'Neill, P.M.; Shanahan, J.F.; Schepers, J.S. Use of chlorophyll fluorescence assessments to differentiate corn hybrid response to variable water conditions. Crop Sci. 2006, 46, 681-687. [CrossRef]

34. Sayar, R.; Khemira, H.; Kameli, A.; Mosbahi, M. Physiological tests as predictive appreciation for drought tolerance in durum wheat (Triticum durum Desf.). Agron. Res. 2008, 6, 79-90.

35. Dane, J.H.; Hopmans, J.W. Pressure Plate Extractor. In Methods of Soil Analysis; Dane, J.H., Topp, E.C., Eds.; Part 4: Physical Methods. SSSA Book Series 5; SSSA: Madison, WI, USA, 2002; pp. 688-690.

36. Karagiannioy, I.; Dordas, C. Evaluation of basil genotypes using physiological and agronomic characteristics. In NAROSSA ${ }^{\circledR}$ 2016. In Proceedings of the Magdeburg, International Conference for Renewable Resources and Plant Biotechnology, Magdeburg, Germany, 13 June 2016.

37. Allen, R.G.; Pereira, L.S.; Raes, D.; Smith, M. Crop Evapotranspiration-Guidelines for Computing Crop Water Requirements; FAO Irrigation and Drainage Paper 56; FAO: Rome, Italy, 1998.

38. Ghamarnia, H.; Amirkhani, D.; Arji, I. Basil (Ocimum basilicum L) Water Use, Crop Coefficients and SIMDualKc Model Implementing in a Semi-arid Climate. Int. J. Plant Soil Sci. 2015, 4, 535-547. [CrossRef]

39. Wichtl, M. Die Pharmakognostichchemische Analys; Band 12. Akademische Verlagsgesellschaft: Frankfurt, Germany, 1971.

40. von Caemmeter, S.; Farquhar, S. Some relationships between the biochemistry of photosynthesis and the gas exchange of leaves. Planta 1981, 153, 376-387. [CrossRef]

41. Steel, R.G.D.; Torrie, J.H.; Dickey, D.A. Principles and Procedures of Statistics: A Biometrical Approach, 2nd ed.; McGraw-Hill: New York, NY, USA, 1997.

42. Gomez, K.; Gomez, A. Statistical Procedures for Agricultural Research; John Willey \& Sons, Inc: Singapore, 1984.

43. Castonguay, Y.; Markhart, A.H. Saturated rates of photosynthesis in water stressed leaves of common bean and tepary bean. Crop. Sci. 1991, 31, 1605-1611. [CrossRef]

44. Ninou, E.; Tsialtas, J.T.; Dordas, C.A.; Papakosta, D.K. Effect of irrigation on leaf and gas exchange physiology, seed yield and quality of dwarf dry bean (Phaseolus vulgaris L.) grown under Mediterranean conditions. Agric. Water Manag. 2012, 116, 235-241. [CrossRef] 
45. Viera, H.J.; Bergamaschi, H.; Angelocci, L.R.; Libardi, P.L. Performance of two bean cultivars under two water availability regimes. II. Stomatal resistance to vapour diffusion, transpiration flux density and water potential in the plant (in Portugal). Pesqui. Agropeularia Bras. 1991, 9, 1045-1053.

46. Lawlor, D.W.; Tezara, W. Causes of decreased photosynthetic rate and metabolic capacity in water-deficient leaf cells: A critical evaluation of mechanisms and integration of processes. Ann. Bot. 2009, 103, 561-579. [CrossRef] [PubMed]

47. Nemeskeri, E.; Helyes, L. Physiological Responses of Selected Vegetable Crop Species to Water Stress. Agronomy 2019, 9, 447. [CrossRef]

48. Abdul-Hamid, A.F.; Kubota, F.A.; Morokuma, M. Photosynthesis, transpiration, dry matter accumulation and yield performance of mungbean plant in response to water stress. J. Fac. Agric. Kyushu Univ. 1990, 1-2, 81-92.

49. Chaves, M.M.; Pereira, J.S.; Maroco, J.; Rodrigues, M.L.; Ricardo, C.P.P.; Osório, M.L.; Carvalho, I.; Faria, T.; Pinheiro, C. How plants cope with water stress in the field. Photosynthesis and growth. Ann. Bot. 2002, 89, 907-916. [CrossRef]

50. Cornic, G.; Fresneau, C. Photosynthetic carbon reduction and carbon oxidation cycles are the main electron sinks for photosystem II activity during a mild drought. Ann. Bot. 2002, 89, 887-894. [CrossRef]

51. Reddy, A.R.; Chaitanya, K.V.; Vivekanandan, M. Drought induced responses of photosynthesis and antioxidant metabolism in higher plants. J. Plant Physiol. 2004, 161, 1189-1202. [CrossRef]

52. Rhizopoulou, S.; Diamantoglou, S. Water stress induced diurnal variations in leaf water relations, stomatal conductance, soluble sugars, lipids and essential oil content of Origanum majorana L. J. Hortic. Sci. 1991, 66, 119-125. [CrossRef]

53. Misra, A.; Srivastava, N.K. Influence of water stress on Japanese mint. J. Herbs. Spices Med. Plants 2000, 7, 51-58. [CrossRef]

54. Valtcho, D.Z.; Callahan, A.; Cantrell, C.L. Yield and Oil Composition of 38 Basil (Ocimum basilicum L.) Accessions Grown in Mississippi. J. Agric. Food Chem. 2008, 56, 241-245.

55. Chaves, M.M.; Oliveira, M.M. Mechanisms underlying plant resilience to water deficits: Prospects for water-saving agriculture. J. Exp. Bot. 2004, 55, 2365-2384. [CrossRef] [PubMed]

56. Lawlor, D.W. Limitation to photosynthesis in water-stressed leaves: Stomata vs. metabolism and the role of ATP. Ann. Bot. 2002, 89, 871-885.

57. Christensen, C.A.; Feldmann, K.A. Biotechnology approaches to engineering drought tolerant crops. In Advances in Molecular Breeding toward Drought and Salt Tolerant Crops; Jenks, M.A., Hasegawa, P.M., Jain, S.M., Eds.; Springer: Berlin/Heilderberg, Germany, 2007; pp. 333-357. 